Man and Nature

L'homme et la nature

\title{
Edmund Burke and the Scottish Enlightenment
}

\section{George McElroy}

Volume 11, 1992

URI : https://id.erudit.org/iderudit/1012681ar

DOI : https://doi.org/10.7202/1012681ar

Aller au sommaire du numéro

Éditeur(s)

Canadian Society for Eighteenth-Century Studies / Société canadienne d'étude du dix-huitième siècle

ISSN

0824-3298 (imprimé)

1927-8810 (numérique)

Découvrir la revue

Citer cet article

McElroy, G. (1992). Edmund Burke and the Scottish Enlightenment. Man and Nature / L'homme et la nature, 11, 171-185. https://doi.org/10.7202/1012681ar

Copyright (c) Canadian Society for Eighteenth-Century Studies / Sociéte canadienne d'étude du dix-huitième siècle, 1992
Ce document est protégé par la loi sur le droit d'auteur. L'utilisation des services d'Érudit (y compris la reproduction) est assujettie à sa politique d'utilisation que vous pouvez consulter en ligne.

https://apropos.erudit.org/fr/usagers/politique-dutilisation/ 


\section{Edmund Burke and the Scottish Enlightenment}

Sir Isaiah Berlin, in his recent New York Review of Books article on 'Joseph de Maistre and the Origins of Fascism, ${ }^{1}$ calls Burke the 'most celebrated and gifted spokesman' of the 'reaction against the central position of the classicism and enlightenment of Paris' which climaxed in 'the violent opposition to the French Revolution,' though he thinks de Maistre outdid Burke in 'sharpness of mind' and polemical brilliance.

But de Maistre was a ferocious anti-rationalist, while Burke tried tirelessly to inject rationality into political decisions. 'We are rational creatures,' he said; 'and in all our works we ought to regard their end and purpose; the gratification of any passion ... ought only to be of secondary consideration. ${ }^{\prime 2}$ It was exile 'from this world of reason, and order, and peace, and virtue' which threatened followers of revolutionary doctrines. ${ }^{3}$ To place Burke in the same camp with de Maistre, merely because both attacked the 'enlightenment' of Paris, shows how little even Sir Isaiah realizes that Burke has to be read as a figure in the Scottish enlightenment, and how much that differs from the Parisian.

The Parisians, and Tom Paine in their wake, were still operating in the tradition of Descartes, for whom, as for other 'rationalists' - Leibniz, Spinoza, Hobbes - mathematics was the model for all philosophy. Rousseau, d'Holbach, and their like no longer shared their predecessors' theological preoccupations nor did all have mathematical training, but, consciously or not, most French philosophes still shared the presumption that philosophical problems could be solved, as in mathematics, by asking whether, given certain clearly defined premises, preferably selfevident, a logical deduction, using 'clear and distinct ideas', as Descartes put it, would prove a conclusion true or false. ${ }^{4}$ Thus, even in politics, precise logical consistency was the ideal, and conclusions could be simple and seemingly obvious.

But, for the Scots, Locke, and Newton had happened, in ways that differed from those affecting even the philosophes who applauded their discoveries. Locke, finding he and his friends were getting into unresolvable intellectual wrangles, had decided that, before trying to prove that they knew something, they had better first ask how they came to 
know anything, and thus find out what they could and could not hope to know. He concluded that all knowledge was based on experience, either of the outside world by sensation, or of one's own mind, by reflection, and this left many questions unanswerable. Newton showed that knowledge of how physical objects regularly acted, and could be predictably expected to act, was advanced by careful deduction from premises established by observation - gravity, laws of motion, action of light - which, so far from being self evident, were inexplicable. He could only suppose that Providence, for its own unknowable reasons, had set them up as the universe's operating rules.

The French, too, had read Locke and Newton, and enthusiastically adopted many of their conclusions - the tabula rasa replaced Cartesian innate ideas, the laws of motion and gravity replace Descartes' vortices. But, wedded to Cartesian geometrical method, they did not necessarily conclude, as did Scots, that the fundamental questions for moral philosophy were, what causes are at work in 'human nature' to explain why we think, feel, and act as we do, and how far, thus, any mental or physical actions can be predictable - the study, as we say more Greekly, of psychology and epistemology, a study inevitably tentative. Both Hume and his critics followed Locke in finding their materials by observation and, particularly, introspection; their model of method was physics and that 'experimental method of reasoning' which Hume explicitly undertook to introduce into 'moral subjects' (by his discovery that the mind's observably invincible propensity to associate ideas as cause and effect, without any possible proof, was the moral 'law of gravity,' the inexplicable starting point for all reasoning). They could not, to be sure, imitate Newton's mathematical deductions (though Hutcheson made a stab at moral algebra), since, e.g. the relative force of an impression and an idea is not quantifiable. But out of such inquiries would grow new investigations of ethics, politics, economics, aesthetics - everything asking how people live, think, and act.

In pursuing them, Scots asked, not whether propositions were logically demonstrable with the mathematical exactness Aristotle warned could not be demanded in subjects where things are, at best, but 'for the most part true, ${ }^{\prime 5}$ but whether there were observable relations of cause and effect. Ultimate causes, as Burke admitted, were out of reach: 'When we go but one step beyorid the immediately sensible qualities of things, we go out of our depth' (SEB Part IV, Sect. 1, 129-30). Most, like Newton and Burke, invoked inscrutable Providence when they reached the inexplicable.

The immediate causes of what people do are the things they think and feel, however stimulated. The complications of human psychology are neither simple nor obvious, but the Scots were grappling with them 
to found political and social science, and Burke was the first important politician to try to introduce their scientific method into political action (Thoughts on the Cause of the Present Discontents, WES II, 317-18). If he dismissed the 'Rights of man' as 'such a pedantick abuse of elementary principles as would have disgraced boys at school, ${ }^{\prime 6}$ and the National Assembly as legislating by the metaphysics of an undergraduate instead of from knowledge of human nature, and of its variations in civil life, ${ }^{7}$ it was because, to an empiricist, they were nearly a century behind in their ideas of what mattered, and how to think about it. "They are sublime metaphysicians.... They only ask whether a proposition be true? Whether it produces good or evil is no part of their concern. ${ }^{8}$

Burke was perhaps a bit ahead of most Scottish thinkers in recognizing how much of human nature is not rational, and insisting that rationally - politics must deal with that nature as it really is, and employ the non-rational, or adjust to it, as usefully as possible. ${ }^{9}$ Hence, probably, the common mis-conception that Burke exalts emotion and prejudice over reason, though he thought even instincts, such as that to shun disgrace, to be 'always right' only when 'under the direction of reason' (Letter to a Noble Lord, Works V, 208-9).

Unquestionably, the work Burke began in college, A Philosophical Enquiry into the Origin of Our Ideas of the Sublime and Beautiful, is in the Scottish line. The title so obviously recalls Francis Hutcheson's An Inquiry into the Original of our Ideas of Beauty and Virtue - 'ideas', in both cases, in the Lockeian sense of the mind's basic reactions, or building blocks - that Burke's old schoolfellow, Richard Shackleton, wrote William Dennis, Burke's college chum, to ask if Burke's work differed from Hutcheson's, which had been published in 1725 when Hutcheson, conducting a dissenting academy in Dublin, was in the center of its lively intellectual circle. He had returned to Glasgow in 1730, as Professor of Moral Philosophy, but in Dublin his ideas and the discussions they started evidently lingered on; in 1744, Burke, age 16, had written Shackleton that beauty consisted in 'Variety and uniformity,' Hutcheson's thesis. ${ }^{10}$ In the Philosophical Enquiry, although it is with Locke that Burke explicitly argues, in distinguishing the 'delight' felt at cessation of danger or pain from positive 'pleasure' ( $S E B, 34$. And see below, n. 24), his long argument in Part III that proportion is not the cause of beauty seems aimed at one of Hutcheson's theses, and, in setting out rules of evidence to be observed in that argument, Burke paraphrases three of Hume's rules for judging of cause and effect. ${ }^{11}$

Hume wrote Adam Smith that the Philosophical Enquiry was a 'very pretty treatise' and that he had sent a copy of Smith's Theory of Moral Sentiments to Burke, with whom he was 'very well acquainted. ${ }^{12}$ Burke, 
in the Annual Register for 1759 , gave Smith as glowing a review as one great thinker ever gave another:

the theory is in all its essential parts just, and founded on truth and nature. The author seeks for the foundation of the just, the fit, the proper, the decent, in our most common and most allowed passions; and making approbation and disapprobation the tests of virtue and vice, and showing that those are founded on sympathy, he raises from this simple truth, one of the most beautiful fabrics of moral theory, that has perhaps ever appeared. ${ }^{13}$

Obviously, Burke was still thinking along Scottish lines. No wonder Smith, later, regularly addressed him as 'my dear friend,' ${ }^{14}$ accompanied him to Glasgow for his installation as rector of the University and a tour of Loch Lomond, and helped get him elected a fellow of the Royal Society of Edinburgh. ${ }^{15}$ Smith said that Burke was the only man who had thought exactly as he did about economics, without previous communication. ${ }^{16}$

They also agreed, as did Hume, with Shaftesbury's and Hutcheson's contention that men have innate, immediate reactions to good or evil deeds, independent of reason or will. (Hutcheson called it a 'sense'; Burke and Hume, frequently, an 'instinct.' Hume also called it a 'sentiment,' as did Adam Smith). ${ }^{17}$ Burke described the delight, which draws us to scenes of distress, mixed with the pain which moves us to relieve the sufferers, as operating 'antecedent to any reasoning, by an instinct that works us to its own purposes, without our concurrence' $(S \mathcal{E} B, 46)$. He undertook to plant Hastings' crimes 'in those vices which the breast of man is made to abhor' (Speech in opening the Impeachment of Warren Hastings, lst Day. Works IX, 337). He hoped to awaken in his hearers 'those generous and noble sympathies which Providence has planted in the breasts of all men, to be the true guardians of the common rights of humanity' (Speech on the 6th Article of Charge, 3rd day. Works X, 311). For Burke and most of the Scots, this was 'natural law' in the same sense as the law of gravity or any relation of cause and effect, such as that, to get more revenue from Ireland, Ireland must first be enabled to make more money. ${ }^{18}$ The moral sense and the laws of causation are equally observable facts, and hence must equally be among Providence's operating rules for the world.

More important than agreement on any particular point was the presumption, shared by the whole Scottish school, that the basic questions to be investigated concerned human nature. Robert Bisset, who had consulted extensively with French Laurence, Burke's close disciple and literary executor, may have been mistaken in saying that Burke, after leaving Trinity College, applied, too late, for the professorship of logic 
at Glasgow; ${ }^{19}$ this report apparently originated from Smith's saying, upon reading Burke's Philosophical Enquiry, that he would be a great acquisition to Glasgow if he would accept a chair. ${ }^{20}$ But Bisset was certainly right that 'Human nature was Burke's favorite study,' and that he most enjoyed writers such as Bacon and Shakespeare, who pictured characters, manners, minds at work, and how these operated in the relations and duties of society. ${ }^{21}$

Burke wrote Malone that a history of the stage, such as that he had prefixed to his Shakespeare, was 'no trivial thing to those who wish to study Human nature in all Shapes and positions'; without it, studying the 'manners and characters of men' only from political history 'must be ... inferior. ${ }^{, 22}$ Burke wrote a poet and critic that he was 'certainly in the right, that the study of poetry [primarily drama] is the study of human nature; and as this is the first object of philosophy, poetry will always rank first among human compositions. ${ }^{23}$

'I have,' Burke wrote, 'endeavoured through my life to make myself acquainted with human nature: otherwise I should be unfit to take even my humble part in the service of mankind' ('Reflections on the Revolution in France,' WES VIII, 185). That, and details of circumstances, were what politicians needed to know. Thus, Grenville had needed a 'greater knowledge of mankind, and a far more extensive comprehension of things' than his legal training and bureaucratic career had provided (Speech on American Taxation, WES II, 432), whereas Rockingham's successful 1766 American policy was built upon the nature of man, and the circumstances and habits' of England and America (A Letter to ... [the] Sheriffs of ... Bristol, Works II, 234). Burke's own proposed economic reforms used the ways, proven by experience to be 'the most effectual, from the nature of things, and from the constitution of the human mind' (Works II, 310).

In his Reflections, Burke derided Revolutionary visionaries, 'so taken up with their theories about the rights of man, that they have totally forgot his nature' (WES VIII, 115), whereas, in his own book, 'the foundation of government is laid ... in political convenience and in human nature, - either as that nature is universal, or as it is modified by local habits and social aptitudes' (An Appeal from the New to the Old Whigs, Works IV, 206-7). For 'the nature of man is intricate' (Reflections, WES VIII, 112) and the 'second nature' produced by conditioning influences is subject to infinite variations; that is why the effects of political measures are seldom quite predictable, and reforms should proceed cautiously, step by step, to see how they will actually work.

In modern American terms this is more a doctrine for liberals than for the dogmatic conservatives who have tried to enlist Burke in their crusades; liberals are reformers, not revolutionists, and as Burke said in 
1790 , 'almost every business in which he was much concerned, from the first day he sat in that House [of Commons] to that hour was a business of reformation' (Speech ... on the Army Estimates, Works III, 220). He insisted that, when a reform was clearly needed, it should be, literally, radical; 'if we do not go to the very origin and first ruling cause of grievances we do nothing' (Speech on ... A Plan for ... the Economical Reformation of the Civil and other Establishments, Works II, 282, 285). His own proposed American conciliation plan (which envisaged something like the Dominion system, i.e., colonies tied to England primarily by affection and history, under some loosely defined supervision, but expected to contribute directly to imperial needs only in time of war), his India Bill (which invented the nationalized company), and negro code all proved too radical for the prevailing powers; so did the impeachment of Hastings, another way of getting at the root causes of Indian misgovernment. Burke's economic reform plan was watered down by his own ministry; all but the least controversial clauses of his bill to reform the Bengal Supreme Court were cut out by Thurlow, on the pretext that more discussion was needed. But all Burke's proposals were, indeed, aimed directly at the basic causes of serious difficulties, and were wholly or partly defeated by politics, not rejected on their merits.

Since, then, genuine political measures should get at causes, and the basic causes are in human nature, any discussion of Burke's politics or of his proposed reforms ought to begin with his ideas about that nature. The obvious starting point is the Philosophical Enquiry; the 'origin of our ideas of the Sublime and Beautiful' lies in basic psychology, and affects much more than our aesthetic reactions. Burke begins with his favorite intellectual tool, a distinction: between positive pleasure, and the reaction from cessation of pain, which he christens 'delight. ${ }^{24}$ Pleasure comes from beauty - anything which arouses love, and consequently serves the end of society, one of our two great ends. Sensorily, we are pleased by things small, smooth, gently varied (for instance: women's bosoms), delicate, clear-coloured - nothing strong. Beauty relaxes.

Delight comes from the sublime: anything which evokes terror and the fear of death, strongest of all emotions, and so involves our other, and greater end, self-preservation. It begets admiration. The unknown is the most terrible and most fascinating: things vast, obscure, dark-colored, suggesting infinity, great strength and power, rugged texture, or else 'general privations ... Vacuity, Darkness, Solitude and Silence.' They produce tension and energy, when not so fearsome as to cause collapse. The sublime cannot exist with mediocrity.

This psychology underlay Burke's thinking throughout his career. A well-ordered, civilized state he regularly calls 'beautiful,' for beauty serves the end of society. As Horace says of poems, so of states: 'Non satis 
est pulchra esse ... dulcia sunto [they must be not only beautiful but tender]. There ought to be a system of manners in every nation which a well-formed mind would be disposed to relish,' for 'to make us love our country our country ought to be lovely' (Reflections, WES VIII, 129). When a people act together, under the 'discipline of nature' their voice is a 'grand chorus of national harmony' (Appeal, Works IV, 176). Ireland's separate but dependent legislature disposed everything 'sweetly and harmoniously' for conserving English dominion while communicating English liberties (Conciliation, Works II, 171). It really might have worked that way, but for Pitt and George III! Never had the moral eye beheld 'so beautiful and so august a spectacle ... as Europe afforded the day before the Revolution in France' (A Letter to William Elliot, May 26, 1795, Works V, 121-2).

The sublime appears - naturally, not by name, but by its unmistakeable characteristics - as beauty's terrible opposite. Repealing the teatax, even while keeping the punitive Boston laws, might, Burke urged, 'though working in darkness, and in chaos, in the midst of all this unnatural and turbid combination ... produce order and beauty in the end' (Speech on American Taxation, WES II, 457). Half a world away, in the 'darkness' and 'gloom' of the Mughal Empire's fall, had 'a star ...risen from the West, that would ... shed down the sweet influence of order, peace, science and security ... it would have been a beautiful and noble spectacle. ${ }^{25}$

But India, instead, produced Burke's most famous 'sublime' set-piece before the French Revolution: Haidar Ali of Mysore, finding he could place no faith in the creditors of the Nabob of Arcot governing at Madras,

resolved, in the gloomy recesses of a mind capacious of such things, to leave the whole Carnatic an everlasting monument of vengeance; and to put perpetual desolation as a barrier between him and those against whom the faith which holds the moral elements of the world together was no protection.... he drew from every quarter, whatever a savage ferocity could add to his new rudiments in the arts of destruction; and compounding all the materials of fury, havoc, and desolation, into one black cloud, he hung for a while on the declivities of the mountains. Whilst the authors of all these evils were idly and stupidly gazing on this menacing meteor, which blackened all their horizon, it suddenly burst, and poured down the whole of its contents upon the plains of the Carnatic. Then ensued a scene of woe, the like of which no eye had seen, no heart conceived, and which no tongue can adequately tell. All the horrors of war before known or heard of, were mercy to that new havoc. A storm of universal fire blasted every field, consumed every house, destroyed every temple. The 
miserable inhabitants flying from their flaming villages, in part were slaughtered; others, without regard to sex, to age, to the respect of rank, or sacredness of function; fathers torn from children, husbands from wives, enveloped in a whirlwind of cavalry, and amidst the goading spears of drivers, and the trampling of pursuing horses, were swept into captivity, in an unknown and hostile land. (Speech on the ... Directions for Charging the Nabob of Arcot's Private Debts to Europeans, on the Revenues of the Carnatic, WES V, 518-19)

But until the French Revolution the destructive sublime appeared only peripherally in Burke's writing; that is one reason why even close colleagues were dumbfounded at his reaction to that revolution. England, whatever its problems, was a civilized country, and since Burke saw civilization as dependent on the peaceful attractions of the social beautiful, suppression of the stronger impulses of the self-centered sublime, he avoided 'sublime' issues until India and France forced them on him. For men, once taught to forget 'order, frugality, and industry' enjoy

[a] retrograde order of society.... The life of adventurers, gamesters, gipsies, beggars, and robbers is not unpleasant. It requires restraint to keep men from falling into that habit. The shifting tides of fear and hope, the flight and pursuit, the peril and escape, the alternate famine and feast, of the savage and the thief, after a time, render all course of slow, steady, progressive, unvaried occupation, and the prospect only of a limited mediocrity at the end of long labour, to the last degree tame, languid, and insipid. (Letter to a Member of the National Assembly, WES VIII, 301)

Mediocrity and the Sublime cannot exist together. Burke hoped his Reflections might give the people 'the wisdom of knowing how to tolerate a condition which none of their efforts can render much more than tolerable' (A Letter To Wm. Elliot, Esq., Works V, 124).

That is, the problem he saw was that of making the weaker impulse defeat the stronger. It was made acute by his discovery of the power and energy of French ideologic fanaticism. Before that Revolution, Burke had believed that when masses of people were discontented, or even rebellious, it was probably because they really felt some grievance, and that they were the sole and indisputable judges of what they felt, although, while rarely wrong in their feelings about public misconduct, they were equally rarely right 'in their speculation upon the cause of it' (Thoughts on the Cause of the Present Discontents, WES II, 255-6). They lacked the education and 'experience in business' needed to judge of the causes and cures of their complaints (Speech on a Bill for Shortening the Duration 
of Parliaments, Works VII, 74-75). It was up to their more sophisticated leaders to find those causes and do something.

But now Burke found that, as we have since experienced all too often, devotion to an abstract idea of government can generate a fanatically blind ruthlessness as great as can any religious fury, and that whereas a felt grievance had limits, and could be specifically remedied, imagination was limitless; it saw useful reforms merely as prolonging the life of a system to be obliterated (Appeal from the New to the Old Whigs, Works IV, 192).

Such problems had not occurred to the Scots, nor did any of them adopt Burke's view of the attraction of the terrible; Reid merely wondered whether he had not been led into it by the similarity between dread and admiration. ${ }^{26}$ Thus, though Burke's thinking grew out of their psychological inquiries, and his methods seem to have been largely those he learned 'in the closet' with their books, while the Sublime and Beautiful entered into their aesthetic inquiries, Burke's politically oriented psychological findings, despite some parallels with Hume and Smith, must be seen more as an offshoot of, than as a contribution to, Scottish psychology.

He of course never wrote another systematic analysis, and there is room here for only his most fundamental observations. They do put politics on a soundly psychological basis. 'All government stands upon opinion' (Speech on the motion for a committee to Inquire into the State of the Representation of the Commons in Parliament, May 7,1782, Works VII, 91); thus George III began his reign possessed of 'the true and only true foundations of all national and regal greatness: affection at home, reputation abroad, trust in allies, terror in rival nations' (Present Discontents, Works I, 456). All in the mind. He and his ministers might have preserved the colonies had they trusted to 'reciprocal esteem and regard' and the 'close affection' begot 'from common names, from kindred blood, from similar privileges, and equal protection' without worrying about formal controls (Conciliation, Works II, 179; Letter to the Sheriffs, Works II, 236). With Ireland, intermarriage and inherited property could be closer ties than any laws or constitutions (Letter to Sir Charles Bingham, Works VI, 128).

Certain basic characteristics, habits, and prejudices normally gave England a civilization so stable it could enjoy liberty with no danger of anarchy. That is why Burke was acutely alarmed, lest the French Revolution's assault on traditional ways and beliefs might appeal to the common love of novelty (Appeal, Works IV, 76) and, breaking down these barriers, let loose the powerful energies of the dangerous, limitless sublime passions, and why, therefore, he set out to arouse all the stabilizing prejudices he could, to combat the fearsome energy of Jacob- 
inism. It is misleading for modern conservatives to cite primarily those writings without noting Burke's own admission that they are only one side of his thinking, and probably overstated (Appeal, Works IV, 94-5).

In bolstering stability, he counted on man being, although a lover of novelty, a 'creature of habit' (Letter to the Sheriffs, Works II, pp. 233, 234. $S \mathcal{E} B, 103$ ), who venerates antiquity (Fragments of a tract relative to the Laws against Popery in Ireland, Works VI, 339), admires and adheres to the establishments of his forefathers (Works IVI, 337), and naturally loves, first his family, then his country, the more if the nation can seem to him like a family, and is something he has inherited and will bequeath (Impeachment, speech in general reply, 4th day, Works XI, 422-3; Reflections, WES VIII, 83-5, 97, 102). Burke warned that, in fact, nations were moral, not natural creatures, and we know too little of what makes them live and work to make pronouncements about their life cycles (To William Elliot, Works V, 124), but it is people's feelings that produce stability. It helped that the English state was identified with religion (Inter alia, Reflections, WES VIII, 148-53). Politically, almost any religion would do, if the people believed it fervently. ${ }^{27}$ Everyone is prejudiced in favor of what is his. Each person's instinctive struggle to keep his property and any distinctions he has wards off injustice and despotism, secures property, and keeps communities settled (Reflections, WES VIII, 187). His innate hatred of injustice and cruelty and his sympathies with others guard 'the common rights of humanity.' (Impeachment, 6th Article, 3rd day, Works X, 311.)

But prejudice and instinct cannot by themselves ensure stability, should a nation and society work so badly the people hate the regime. Other human characteristics need to be used helpfully to make the system effectively do its job: promoting the welfare of the governed. One characteristic that Burke thought particularly useful in helping any government to compose its subjects' minds and conciliate their affections - the prerequisite of stability - is the universal desire for reputation, 'the most precious possession of every individual' (Present Discontents, WES II, 252). Though most ordinary people may, most of the time, be moved largely by concern for their interests, all try to protect their dignity and shun disgrace (Letter to a Noble Lord, Works V, 208-9). Everyone wants to feel important, but if he is not rich, he can do so onlybyjoining some group (Letter to Sir Hercules Langrishe, Works IV, 256), and 'loving his little platoon' is the germ of love of country and mankind (Reflections, WES VIII, 97-8) though the resultant esprit de corps means no body of men can be trusted to check itself (Impeachment, opening, lst day, WES VIII, 286, 290 ). Though only a few are ambitious for power and glory (Letter to a Noble Lord, Works V, 208), a 'passion for Fame... is the instinct of all great souls' (Taxation, WES II, 453) and 'the best of all earthly rewards' is 'the 
love and admiration of his fellow citizens' (Taxation, WES II, 443). Since such glory 'is the appetite but of a few' (Letter to a Noble Lord, Works V, 208), only the man who shows he puts his reputation before his interest can be trusted with the power which a society's leaders must have in order to serve it (Present Discontents, WES II, 279), and even so power corrupts (Opening Impeachment, 3rd Day, WES VI,375), and is both addictive and self-aggrandizing; ${ }^{28}$ the only remedy, as in Burke's plans for economic and Indian reform, is to make responsibility clear and accountability public, so that misdeeds promptly lead to infamy, world-wide and long-lasting if they are as serious as were Hastings.'

Only with good leaders, and in a stable society, as contrasted with the measures of the National Assembly, can the 'vicious and degenerate part of human nature' (Fourth Letter on a Regicide Peace, Works VI, 62) be checked. Our vicious proclivities take many forms: e.g., men angry at bigoted persecutions do not attack bigotry but want, in their turn, to persecute the bigots and the whole party they belong to (Fragments of a Tract relative to the Laws against Popery in Ireland, Works VI, 331); they attack individuals for faults in institutions (Economic Reform, Works II, 318); they will endure the vexations of an inefficient system rather than give up the opportunity of vexing others (Economic Reform, Works II, 292-3); and in their eagerness to sacrifice enemies they ignore dangers they incur for themselves (Letter to the Sheriffs, Works II, 198). Even worse, if they once believe they are free to act as they will, exercising that will can lead to chaos and inhumanity; arbitrary will is 'the last corruption of ruling power,' but if the people are flattered into believing government depends on their pleasure, it will poison their hearts, too (Appeal from the New to the Old Whigs, Works IV, 184).

Many other traits, such as the instinct to revenge an injury, can be either useful or harmful, depending on how they are channelled. That involves many things which influence men's predilections for better or for worse, ranging from one's close friends and associates (both vice and virtue are catching)(Letter to the Sheriffs, Works II, 238-9, 242), through the manners and morals of one's society, plus a list of customs and circumstances which could have served Dr. Gallup - birth, education, profession, age, residence in town or country, ways of getting and securing property, and kind of property (Reflections, WES VIII, 231-2) - to the frame and policies of government. Thus one test of government is, what traits does it encourage or discourage? Civil war dulls the natural 'taste' for equity and justice (Letter to the Sheriffs, Works II, 243); manipulation of the funds encourages the universal and pernicious love of gambling (Reflections, WES VIII, 240-1. Economic Reform, Works II, 293).

Good or bad, all these influences, together with the prejudices, opinions, habits, and sentiments acquired throughout life, produce in every- 
one a 'second nature' as powerful as the universally innate first nature (Reply, 7th Day, Works XII, 164), but infinitely more various. That is one reason why the practical science of government 'requires more experience than any person can gain in his whole life' (Reflections, WES VIII, 112), and 'more minds than one age can furnish' (Reflections, WES VIII, 217-18). That is why anyone should be cautious about destroying any institution that has, for ages, answered in any tolerable degree the common purposes of society.' But if he must build something new, he should look for proven models to guide him (Reflections; WES VIII, 112). That is also why no one person should ever have sole power; a number of minds will always do better than one. ${ }^{29}$

Still, even one man's careful observation and analysis of how human nature is working can get valid results. Burke found the Americans' high spirit of liberty had ineradicable causes, and that it must be, sooner or later, accepted (Conciliation, Works II, 120-39). It was. He noted that the French National Assembly was dominated by petty lawyers, who were bound to be power-drunk at their sudden elevation (Reflections, WES VIII, 93-4). They were; one was Robespierre. I suspect that further reading of Burke's view of psychology might lead us to some useful inquiries. They would lead us nowhere near fascism.

\section{GEORGE McELROY \\ Chicago}

\section{Notes}

1 XXXVII, no. 15 (Oct. 11, 1990), 54. This is in the second part of a three-part article, since re-printed in Henry Hardy's edition of Berlin's essays, The Crooked Timber of Humanity: Chapters in the History of Ideas (New York: Knopf, 1991). Elsewhere in the essay, Berlin notes many important differences between Burke and de Maistre, but he lumps Burke with conservatives who thought 'reason, in the sense of a capacity for abstraction or ingenious calculation, or for classification and analysis of reality into ultimate ingredients ... a figment of the philosophes' shallow imagination' (no. 14, Sept. 27, 1990, 59); and he does not seem to notice that when de Maistre excoriates the method of the natural sciences - 'to classify, abstract, generalize, reduce to uniformities' - as 'fatal to the understanding' (62) or contends that all secular reformers and intellectuals, men with faith in individual reason or the individual conscience, those who believe in individual liberty or the rational organization of society, belong to 'la secte' which must be rooted out (63), de Maistre is - no doubt unconsciously - consigning Burke, too, to outer darkness. Conor Cruise O'Brien, reviewing The Crooked Timber of Humanity (New York Review of Books, April 25, 1991, 58-9), also objects to Berlin's listing of Burke among 'reactionary' thinkers - Hamann, Möser, Maistre - 'a galley on which Burke would never have voluntarily embarked,' only for his 
opposition to the French Revolution: 'Burke was no more a reactionary than Isaiah Berlin is. He was a liberal and pluralist opponent of the French Revolution.' O'Brien adds that Philippe Raynaud's preface to the latest French translations of Burke's Reflections defines Burke's position precisely as 'liberal and counter-revolutionary.'

2 A Philosophical Enquiry into the Origins of our Ideas of the Sublime and Beautiful, ed. J.T. Boulton (London: Routledge and Kegan Paul, 1958), 109. All further references to the Philosophical Enquiry (abbreviated $S \mathcal{E} B$ ) are to this edition and will be further quoted in the text.

3 The Writings and Speeches of Edmund Burke vol. VIII, The French Revolution 1790-1794, ed. L.G. Mitchell (Oxford: Clarendon Press, 1989), 147. Further references to those of Burke's works printed in those volumes of the Oxford edition which have so far appeared (Vols. II, V, VI, VII, IX) are to this edition, abbreviated WES and will be further quoted in the text. Works, other than the Philosophical Enquiry, that are not in these volumes, are taken from The Works of the Right Honorable Edmund Burke, 9th edition (Boston: Little, Brown, 1889), abbreviated Works, and will be further quoted in the text.

4 D'Alembert, in his Encyclopédie article on Descartes, (Paris, 175l, II, 723-4) agreed with Fontenelle that 'On peut ... féliciter le siècle qui, en nous donnant Descartes, a mis en honneur un nouvel art de raisonner et communiqué aux autres sciences l'exactitude de la Géométrie,' though he also agreed with Fontenelle that Descartes had (aside from mathematics) been too often precipitate in choosing less than certain premises as the basis of his deductions. That is, D'Alembert, himself a mathematician, disagreed with many of Descartes' conclusions, but approved his method. Condillac, in the introduction to his Essai sur l'Origine des Connoissances Humaines, follow-up of Locke though it evidently was, explained that, in looking for the reasons why metaphysicians seemed to him 'De tous les philosophes ... les moins sages,' he had studied their methods and promptly saw, by contrast, 'la route que je devois prendre. Il me parut qu'on pouvoit raisonner en métaphysique et en morale avec autant d'exactitude qu'en géométrie; se faire, aussi bien que les géomètres, des idées justes; déterminer, comme eux, le sens des expressions d'une manière précise et invariable; enfin se prescrire, peut-être mieux qu'ils ont fait, un ordre assez simple et assez facile pour arriver à l'évidence.' Georges Le Roy, ed. Oeuvres Philosophiques de Condillac (Paris: Presses Universitaires de France, 1947), I, 3.

5 Nichomachean Ethics Bk. I, Ch. 3 (1094b, 12-29). The Basic Works of Aristotle, ed. Richard McKeon (New York: Random House, 1941), 936.

'Aristotle, the great master of reasoning, cautions us ... against this species of delusive geometrical accuracy in moral arguments, as the most fallacious of all sophistry': Burke, On Conciliation with the Colonies, Works II, 170.

6 Speech ... on the Army Estimates, Feb. 9, 1790, Works III, 221. This account is a collaboration. Burke's brother Richard wrote the first eleven paragraphs, and Burke's son, Richard Jr., the last nineteen - except that someone else, perhaps French Laurence, inserted a paragraph (the second and the 27th) into each group. Edmund wrote the middle twelve paragraphs, including this passage. This distribution is based on my analysis of sentence and paragraph lengths, plus proportions of sentence types. See the appendix to my 'Edmund, William and Richard Burke's First Attack on Indian Misrule, 1778,' Bodleian Library Record, Fall, $1798,62-5$. 
7 'This sort of people are so taken up with their theories about the rights of man, that they have totally forgot his nature.' Reflections on the Revolution in France (hereafter, Reflections), WES VIII, 115.

8 To William Weddell, Jan. 31, 1792, The Correspondence of Edmund Burke (Chicago: University of Chicago Press, 1978), 958; hereafter Corr., VII, 63.

9 'Politics ought to be adjusted, not to human reasonings, but to human nature; of which the reason is but a part, and by no means the greatest part.' Observations on a Late Publication, Intituled 'The Present State of the Nation,' Works I, 398.

This pamphlet, too, is a collaboration. The passage referred to is in Edmund's portion.

10 To Richard Shackleton, circa 14 June, 1744, Corr. I, 18. Burke had sent copies of the Philosophical Enquiry to Shackleton and to Dennis. Dennis wrote Shackleton, in March 1758, that it differed 'A great deal.... One is a moral, the other a critical work. The moral piece corrupts and the critical enlarges the understanding. Hutchinson's [sic] treatise is an establishment of morals from the Beauty, order, fitness and rectitude of actions, and this indirectly saps religion by representing virtue independent of it; but our friend anatomizes our passions and the objects of them, and thus teaches by sound logical principles how the arts are to be judged, and how the Artist or Writer is to operate if he is to affect the soul with sublimity and beauty.' Arthur P.I. Samuels, The Early Life Correspondence and Writings of The Rt. Hon. Edmund Burke LL.D. (Cambridge: University Press, 1923), 214.

11 Burke's Rule \#l: 'If two bodies produce the same or a similar effect on the mind, and on examination they are found to agree in some of their properties, and to differ in others; the common effect is to be attributed to the properties in which they agree, and not to those in which they differ.'

Hume's \#5: 'where several different objects produce the same effect, it must be by means of some quality, which we discover to be common amongst them.'

Burke's \#4: 'not to admit any determinate quantity, or any relation of quality, as the cause of a certain effect, if the effect is produced by different or opposite measures and relations; or if these measures and relations may exist, and yet the effect may not be produced.'

Hume's \#4: 'The same cause always produces the same effect, and the same effect never arises but from the same causes.'

Hume's \#8: 'An object which exists for any time in its full perfection without any effect, is not the sole cause of that effect.' (Close to Burke's point, except that Burke is not raising a question about contributory causes). SEB, 93-4; $A$ Treatise of Human Nature ed. L.A. Selby-Bigge (Oxford: Clarendon Press, 1949), 173-4. In his 'Conciliation' speech, Burke was to invoke Hume's Rule \#2 - 'the cause must be prior to the effect' - to argue that taxation, not the commercial laws, was the cause of American unrest (Works II, 144).

12 To Smith, April 12 and July 28, 1759. J.Y.T. Greig, ed. The Letters of David Hume (Oxford: Clarendon Press, 1932, reprinted 1969), I, 303, 312.

13 Second part, p. 485. My stylometric analysis confirms that this review is Burke's.

14 To Burke, 1 July, 1782; 15 April, 1783. Corr. V, ed. Holden Furber, 3, 86.

15 John Rae, Life of Adam Smith (New York: Reprints of Economic Classics, August M. Kelly, 1965), 387-91; 393-4.

16 Ibid., 387-8. 
17 See e.g. Smith, The Theory of Moral Sentiments, ed. D.D. Raphael and A.L. Macfie (Oxford: Clarendon Press, 1976, reprinted 1979), II, i, 2, 5, 71; and II, i, 5, 10, 77; Hume, Treatise Bk. II, Part III, iii, 417.

18 To Samuel Span, 23 April, 1778. Corr. III, 434.

19 Robert Bisset, The Life of Edmund Burke (London: George Cawthorne, 1798), 21.

$20 \mathrm{Rae}, 46-7$.

21 Op. cit. 149-50. Gladys Bryson points out that Bacon and Newton were the masters the Scottish philosophers repeatedly said they would follow. Man and Society: The Scottish Inquiry of the Eighteenth Century (New York: Augustus M. Kelley, Reprints of Economic Classics, 1968), 18. Perhaps an Irishman was more ready than were Scots to find a playwright, too, a source of moral knowledge. Bryson's introductory chapter discusses in greater detail several of the points I have made concerning the Scottish school.

22 [circa 29 Nov. 1790.] Corr. VI, 181.

23 To William Richardson, 18 June, 1777. Corr. III, 354.

24 SEB Part I, Sections III, IV, pp. 33-7. In his preface to the first edition, Burke premised that 'the ideas of the sublime and beautiful were frequently confounded; and that both were indiscriminately applied to things greatly differing, and sometimes of natures directly opposite' (l).

25 Impeachment, Opening, 2nd day, Works IX, 398. This is Burke's revision of the shorthand report; the somewhat less colorful original is given in WES VI, 314-15.

26 'Essay on the Intellectual Powers of Man' in Philosophical Works (Hildesheim: Georg Olms, 1967), 498.

27 Burke frequently insisted that Catholics and Protestants of many sorts were not only equally good Christians, but equally good citizens, and he urged that if the French monarchy were restored, the established Catholic church be restored with it ('On the Policy of the Allies,' WES VIII, 488). '[N]othing is so fatal to religion as indifference' (to Wm. Smith, Jan. 29, 1795, Works VI, 365). He deplored any attack on the Moslem and Hindu religions in India (to Edmund Sexton Perry, 16 June, 1778, Corr. III, 437-8); he credited Hinduism with making countries flourish where it prevailed, and with a powerful, if mysterious influence in maintaining laws and institutions despite repeated foreign conquests (Impeachment, Opening, 1st day, WES VI, 304-5).

28 Letter to a Member of the National Assembly, WES VIII, 301: '[A]ll men, and without any evil intentions, will naturally wish to extend their own jurisdiction, and to weaken all the power by which they may be limited and controlled' (Report from the Committee of the House of Commons, Appointed to Inspect the Lords' Journals ... on the Trial of Warren Hastings, Works XI, 58.

29 Speech opposing an amendment to Pitt's India Act, to give the Governor General power to over-ride his Council (Parliamentary History XXV, 1276-77). 